\title{
The Value of Ideological and Political Education Ruled by Law Under The View of Rule of Law Culture
}

\author{
Lan-Fang WU \\ North China Electric Power University, Baoding, Hebei China \\ hdwlf@163.com
}

Keywords: Rule of law culture ,Ideological and political education, Rule of law, Value

\begin{abstract}
The current ideological and political education is in the environment of rule by law. The theory of ruling the country by law also puts forward certain requirements for the development of Ideological and political education. In the era of rule by law, the rule of law culture is an important cultural resource of Ideological and political education. It requires ideological and political work to develop towards legalization. This is the inevitable trend of Ideological and political education advancing with the times and innovating.
\end{abstract}

\section{Introduction}

The rule of law culture emphasizes the authority status of law in social life and is the ruler of people's social activities. Ideological and political work is the lifeline of all works. In this sense, the legalization of Ideological and political education is a very worthwhile subject under the rule of law culture.

\section{The Significance of The Rule of Law Culture To Ideological and Political Education Ruled By Law}

The rule of law culture is a kind of rational culture, which originated from the western modern democratic politics, democracy, freedom and justice as value orientation, to limit public power and the protection of citizens' rights for the purpose. It is a kind of social governance model, people realize their own liberation, the pursuit of higher goals and tools.

(1) The meaning of the rule of law culture.

The rule of law culture is a common sense of rule by law after long history accumulation, and the sum of legal norms and rule of law activities governed by such values.

The culture of the rule of law is decided by the social basis of market economy and democratic politics. It emphasizes establishing complete legal system, pursuits "justice" value orientation, and internalizes in the legal infrastructure, people's ideas and way. It's a reasonal legal culture condition which core contents are to regulate public power of state organs and safeguard the legitimate rights and interests of citizen. The rule of law culture has gone beyond the general study of legal culture. It is more prominent arounding the purpose of rule of law, focusing on problems of rule of law and revealing the reality of rule of law, so as to form an advanced legal culture that will lead to the development of modern rule of law as soon as possible.

The rule of law culture in a broad sense includes not only the content of system, such as legal norms, legal system and legal organization facilities, but also people's spiritual aspects of law thought, rule of law theory, law consciousness, emotion, belief and so on.

(2). The significance of the rule of law culture for Ideological and Political Education ruled by law.

At present, the cultural level of the rule of law has become the most significant manifestation of the state's soft power, and it is also the conventional way of governance of the modern government. People advocate the rule of law and carry out the rule of law. The governance ruled by law is the most effective form of governance. it in a rational way, can be expected to provide a broad and complex social life, reduce friction, reduce transaction costs, improve governance efficiency; The rule of law governance can be both short-term and long-term goals of human development, and promote the coordination the development of politics, economy, culture and society, and the 
relationship between the ecological environment and through the mediation of intergenerational development, ensure sustainable development; But also because of the differentiation of interests, values diversified situation, the rule of law governance has proven to be the most effective means of integration of social order. [1] In today's complex and competitive world, the rule of law culture is the core factor affecting the competitiveness of a country and society.

The rule of law culture as a kind of ideology, behavior and concept of civilization, has a special strength. It promotes the process of democracy and law of great inner power, also has a significant role in the ideological and political education ruled by law. They are embodied in the following aspects:

1) The rule of law culture is an important source of promoting national cohesion

National cohesion is the spiritual pillar of a country or nation, and the national spirit is the soul of a nation. It plays an immeasurable role in shaping national character and style and enhancing national cohesion and centripetal force. The rule of law culture can make social life and social relations into the legal track, the promotion of social justice and social order and social progress, and ultimately the formation of a strong national cohesion, create a good social environment to enhance the country's soft power, national rejuvenation and prosperity of the country to provide important support. [2]The rule of law is deeply rooted in the Chinese fertile soil, with distinctive national style and Chinese characteristics, with unique personality and independent character. The cohesive force displayed by the rule of law culture is the crystallization of human wisdom, the precious wealth of human civilization, and an indispensable and important resource for maintaining social order and stability.

2) The rule of law culture is the key factor to highlight the attraction of culture

The rule of law culture is the core factor of culture. In all kinds of culture, the rule of law culture plays a key role. This role is reflected in: on the one hand, the rule of law culture is in a dominant position in other cultures. This dominance is determined by the authority of the Constitution and the law. On the other hand, the rule of law culture can provide security, motivation, or other cultural forms for other cultural forms. [3] It is in this sense that the study of the rule of law culture has the key meaning of cultural attraction. In the strategy of the rule of law, strengthen the civic education concept of the rule of law, whether the construction of the rule of law, or the socialist cultural development and prosperity, are required to pay attention to the rule of law culture, which embodies the culture of the rule of law is the key factors to reflect the cultural attraction and the rule of law culture in the whole strategy and the role of cultural power important significance.

3) The rule of law culture transforms legal constraints into the rule of law

People's social behavior is always subject to the restriction of law. As a driving force, the rule of law culture can enable people to grasp the requirements of law in a deeper level and transform legal constraints into rule by law. As a kind of ideological ideology, the rule of law culture plays a leading role in social law enforcement and law-abiding. Especially in the process of rule by law modernization, the correct implementation of law depends on the Enlightenment of rule by law culture. The concept of unity of rights and obligations characterized by equality should play a leading role in the rule of law culture. Equality before the law is the core of social members' legal cognition. Respecting human rights and protecting human rights has become a universal concept. In the concept mode of respecting human rights, it includes supervision and restriction of public power. The state has the obligation to respect and protect human rights, and create social environment and necessary conditions for the full realization of human rights.

4) The rule of law culture has the powerful function of integrating social forces, standardizing social behavior, maintaining social order and guiding social morality.

This is the cornerstone and soul of the construction of the rule of law for the comprehensive promotion of the rule of law and the construction of a rule of law society. The construction of rule by law culture in Colleges and universities can correctly handle all kinds of contradictions in training teachers and students' legal thoughts, legal awareness, legal beliefs, promoting the rule of law and promoting the rule of law in universities, and coordinating the interests of all aspects of the 
school. The construction of the rule of law culture in Colleges and universities is also the core content, cultural foundation and essence of the rule of law of Ideological and political education.

\section{The Necessity of the Rule of Law of Ideological and Political Education under the View of Rule of Law Culture}

The current ideological and political education is in the environment of rule by law. The theory of ruling the country by law also puts forward certain requirements for the development of Ideological and political education. Ideological and political education, as the work to determine the basic value of society, must be based on the value orientation of the whole society. The basic strategy of rule of law requirements of the ideological and political work, the autonomy of work to general guidelines for the concept of the rule of law of common identity as members of society, requirement of Ideological and political work through the development of legal system itself, combined with the spirit of the times, to better achieve the goal of social development service. At present, we must strengthen the ideological and political work by means of law. We must first improve the laws and regulations in all aspects of Ideological and political education, which is a prerequisite. At the same time, in carrying out ideological and political work, we should pay more attention to rule of law education, set up legal awareness, and make ideological and political education develop towards legalization. This is the inevitable trend of Ideological and political education advancing with the times and innovating.

The legalization of Ideological and political education is to pour the spirit and principles of rule of law into all levels of Ideological and political education in politics, economy, culture and social life. It is not a simple stylization of the concept of rule of law, but a trend of human civilization of rule of law. This is the inevitable trend of Ideological and political education advancing with the times and developing and innovating.

\section{The Inevitable Result of the Construction of Political Civilization}

Ideological and political education is the main means of political socialization, and the main way to realize political civilization. The primary purpose of rule of law in Ideological and political education can be said to be an active systematic construction of the party in the ideological field according to law, and an important supplement to the content of the party's political civilization construction. Therefore, the development of Ideological and political education will gradually emphasize the guarantee role of rule of law for ideological and political freedom, and ideological and political education will eventually move towards the rule of law. The significant symbol of political civilization is the civilization of the rule of law in society. The inevitable result of the social and political civilization is the rule of law of Ideological and political education.

\section{(2) Objective Requirements for Deepening the Development of the Rule of Law Economy}

In order to adapt to the development of the rule of law, the rule of law market economy requires that the ideological and political superstructure must follow the rule of law. The economic essence of the rule of law in the market economy requires the legalization of Ideological and political education. The complexity of market main body and dispersion of each subject need to understand the legal rules of the market economy, clear their rights and obligations, to the rules, so as not to damage the integrity of the social development, the pursuit of high visible market economy credit special ethics objectively requires the ideological and political education legalization. The marketization of social economy and the emergence of diversified market players must have the legal system of Ideological and political education to clarify the power of Ideological and political education and the right of Ideological and political education of market participants.

\section{(3) The Inevitable Requirement of the LEADING ideology and the Development of Citizen Consciousness}

China is still in the period of social transformation, and the awakening of civic awareness is manifested in many aspects, such as the spirit of freedom in civic awareness and the rising demand for justice, freedom, equality and rights. Such a citizen consciousness, which reflects the needs of 
social change and the pursuit of individual's all-round and free development, is bound to be reflected in the value idea of Ideological and political education, so as to promote the renewal and transformation of the value concept of the whole ideological and political education. The basic meaning of the value concept of the rule of the conversion coincides with the basic spirit and goal fit. It can be seen that the legalization of Ideological and political education is a powerful guarantee for ensuring the dominant position of socialist consciousness, and it is also the inherent requirement and inevitable result of the development of citizen consciousness in China.

\section{The Urgent Need to Get Out of the Plight of Moral Anomie}

At present, due to the diversity of evaluation criteria, people can find a positive or negative evaluation basis of one or more values based on the evaluation of whether a behavior is moral, which also makes people increasingly fall into deep ideological confusion and moral confusion. Coupled with the rationalization of the evaluation standards in the socialist moral system and the separation from social reality, it is very easy to see that the moral standards in theory are inconsistent with the standards in practice, and even seriously deviate from the phenomenon of socialist moral standards. [4]This shows that play a guiding role in the concept of socialist moral mainstream, not only by simple propaganda, and the ideological and political education as one of the most important means of China's moral education, we must use legal means to improve the level of people's socialist morality.

\section{Means and Guarantee of Ideological and Political Education in Colleges and Universities}

The development of the ideological and political education work must use legal means to optimize the education policy environment, bound by the legal system, and focus on policy implementation to further establish and improve the relevant rules and regulations, to achieve unified policy guidance and practical needs. In the same way, the rule of law is the guarantee of the solid development of the ideological and educational work in Colleges and universities. The essence of the rule of law embodies the people-oriented educational concept, the process of democratic decision-making is the main demands of the pluralistic integration of students; rule of law through legislation, law enforcement and other means to forcibly resolve various contradictions and problems in the process of Ideological and political education, to realize the balanced allocation of resources. The work of Ideological and political education must also adhere to the overall harmonious and sustainable development path, the rule of law is the environment of Ideological and political education work in Colleges and universities continue to improve and optimize the results, effectively realize the overall development of College Ideological and political education, thus become the inevitable choice of the establishment of University Thought Political Education Legalization pattern.

\section{Needs of the Development of Ideological and Political Education in the Context of Harmonious Rule of Law}

The harmonious rule of law is the foundation of the ideological and political education. To realize the harmony of the whole society is the premise of equal rights, reasonable distribution, equal opportunity and justice, but these alone is not enough to maintain the virtue, we must rely on the harmonious rule of law to properly coordinate the interests of all sectors of society, harmonious society is the effective way to achieve fairness and justice. At present, ideological and political education is also facing new opportunities and challenges. Judging from the perspective of harmonious rule of law, the development of Ideological and political education requires order and rule of law, and we must have a stable educational teaching order and a stable surrounding environment. It is the source of Ideological and political education to treat every educator with fairness and impartiality. We can see that ideological and Political Education under the perspective of harmonious rule of law should be a just education. The management innovation of harmonious ideological and Political Education under the rule of law, from the theory, to grasp the details, creating situations, by emotion, mind, through the scientific management of the scattered fire together, amplification efficiency, will light, there will be heat, in order to illuminate the sky, create 
the miracle of the ideological and political education. [5]Therefore, the rule of law in the context of the harmonious rule of law is not only a standard requirement, but also an effective guarantee mechanism for the development of Ideological and political education in the new period.

\section{Conclusion}

The cal and political education of the rule of law has become an inevitable trend of social development, especially from the perspective of legal culture under the overall strategy of ruling the country by law, promoting the ideological and political education of the rule of law, to avoid the shortcomings of the traditional ideological and political education work, given the new connotation of the times, a new exploration of Ideological and political education in the new era.

\section{Acknowledgement}

This research is the stage result of the Cooperative Innovation Center (Peking University) of the theoretical research on socialism with Chinese characteristics in Beijing colleges and Universities.

\section{References}

[1]Zhang Zhiming, A brief analysis of national soft power. Legal Daily, 7(2007).

[2]Li Dong, Cultural and national image, international influence, Contemporary world, 12(2005).

[3]Zhao Xuechang, On the cultivation of the culture of the rule of law, Forum on contemporary education, 7(2007).

[4]Wu Qiong, Research on the rule of law of Ideological and political education, Wuhan University of Science and Technology,2011.

[5]Zhu Guoliang and Zhao Dehai, The harmonious rule of law and ideological and political education, Science and Technology Innovation Herald, 1(2009). 